\title{
A Serial Mediation Model of Perceived Organizational Support on Turnover Intention: The Role of Job Crafting and Thriving at Work
}

\author{
Suchuan Zhang \\ School of Economics and Management, Shanxi University, China \\ Wenzhao Zhang \\ School of Economics and Management, Shanxi University, China
}

Received: Dec. 18, 2020 Accepted: Jan. 6, 2021 Online published: Jan. 28, 2021

doi:10.5296/ijhrs.v11i1.18078

URL: https://doi.org/10.5296/ijhrs.v11i1.18078

\begin{abstract}
The purpose of this paper is to increase understanding of the influence mechanisms of perceived organizational support (POS) on turnover intention, through job crafting and thriving at work. Two-wave data from 541 full-time employees working in northern China were collected. The hypotheses were tested using hierarchical linear regression analysis with the PROCESS plug-in for SPSS to determine the significance of mediators. The results showed that though job crafting did not mediate the POS-turnover intention relationship alone, it interposed in this relationship by affecting thriving at work. This study suggests that a supportive work environment that inspires employees to redesign their jobs and thrive at work plays an important role in helping retain staff. From an employees' self-development perspective, this study proposed a serial mediation model to extend understanding of POS turnover intention relationship.
\end{abstract}

Keywords: perceived organizational support, job crafting, turnover intention, thriving at work

\section{Introduction}

Turnover has always been a concern to organizational managers because of its high costs. In the modern society, the relationship between an organization and its employees becomes more and more unstable, and thus the organization's ability to retain highly qualified employees becomes the basis for competitive advantage and sustainable development of enterprises (Pfeffer, 2005). As a reflection of the employees' desire to leave the organization, 
turnover intention can better predict turnover behavior (Griffeth et al., 2000). Thus, many researchers devote attention to understand the antecedents of employees' turnover intention. Furthermore, an increasing focus on the contextual variables as the cause of turnover intention becomes a major trend in turnover research (Holtom et al., 2008). In particular, as an important organizational factor to attract and retain employees, POS has been highly valued by scholars (DeConinck and Johnson, 2009). Based on social exchange theory, numerous empirical studies have confirmed that POS has a positive effect on work-related attitudes and outcomes, such as work engagement (Bogler and Nir, 2012), job satisfaction (Ngo et al., 2013, Cheng and O-Yang, 2018), organizational commitment (Celep and Yilmazturk, 2012, Panaccio and Vandenberghe, 2009) and organizational citizenship behavior (Afsar and Badir, 2016). It is reasonable that POS as a cause that past research identified to predict positive work-related attitudes and outcomes, in general, can also predict less turnover intention. Thus, there might be a negative relationship between POS and turnover intention.

In order to understand the full array of mechanisms through which POS affects turnover intention, previous scholars have made great efforts to explore a more complete model of the POS-turnover intention relationship which shows that POS can be a distal determinant of turnover intention (Dawley et al., 2010). Indeed, many scholars have paid attention to investigating possible mediators of the relationship between POS and turnover intention, such as organizational commitment (Zopiatis et al., 2014, Arshadi, 2011), job satisfaction (Allen et al., 2003, Baranik et al., 2010) and psychological contract (Paillé, 2015). However, a common perspective in these studies is that they all rely on social exchange theory-that is, employees who receive support from the organization feel obligated to reciprocate this positive treatment by enhancing their willingness to stay at their organization (Park et al., 2015). In contrast, little empirical attention has been paid to the employees' self-development process. Unlike the conventional development process which treats individuals as passive recipients whose attitude can be predetermined entirely by managerial actions, self-development treats individuals as proactive players who are at the forefront of the development process (Meijerink et al., 2018, Antonacopoulou, 2000). Individuals are free to choose their goals and decide how to achieve them. Thus, it is essential to focus on employees' proactive behaviors as well as their psychological states in the workplace. In addition, Maertz et al. (2007) advised that scholars should detect other mechanisms besides organizational attitudes, through which POS affects turnover intention. In order to fill these gaps, this study draws upon a self-development perspective to more fully understand the association between POS and turnover intention by introducing job crafting and thriving at work as mediators. In line with recent work that highlights employees are proactive participants who can craft their job and regulate their behaviors according to how they feel (Nielsen et al., 2013), we treat the two mediators as the part of employees self-development process. Employees are able to make use of their skills and resources to craft their job proactively, and further get the opportunity to grow and thrive at work (Tims and Bakker, 2010). Moreover, employees who thrive at work are better able to improve and sustain their professional development and efficiency (Spreitzer et al., 2012). Individuals who have obtained growth and development opportunities may increase their commitment to the organization. Thus, as a way of promotion and growth, self-development is also beneficial to 
the organization. In such a view, we argue that POS is positively related to job crafting which further leads to thriving at work and, ultimately, to lower turnover intention.

Our study aims to make three important contributions. First, this paper aids in our understanding of the impact of POS on turnover intention. Although many studies have reported a negative relationship between POS and turnover intention, the mechanism to explain this relationship remains to be explored. With this question in mind, we sought to complement the literature on the relationship between POS and turnover intention by examining the mediating effects of two constructs: job crafting and thriving at work. Second, this theoretical effort may help to better explain turnover. Steel and Lounsbury (2009) reported that the overall variance in turnover explained is still limited, though many theoretical constructs can help explain turnover. This study promotes the exploration of this theme by examining the POS, job crafting and thriving at work as predictors of turnover intention. Finally, as organizations increasingly seek to reduce turnover, our study also informs important practical interventions by establishing the links between POS, thriving at work, job crafting and turnover intention.

\section{Hypotheses}

\subsection{POS and Turnover Intention}

Employers expect employees to be committed to the organization, while employees pay close attention to how the organization treats them. Employees with high POS are more likely to make a favorable response to the organization by displaying a positive work attitude or behavior (Rhoades and Eisenberger, 2002). POS is often referred to as employees' general perception concerning the extent to which the organization values their contributions and cares about their well-being (Eisenberger et al., 1986, Eisenberger and Stinglhamber, 2011, Eisenberger et al., 2001). Employees with high POS are willing to remain in the organization which conveys the message that employees are valued by their organizations (Chiang and Hsieh, 2012). According to organization support theory (Eisenberger et al., 2001), employees with high POS are better able to identify themselves with the organization (He et al., 2014) and feel obligated to help the organization achieve its goals and objectives (Hur et al., 2019). In other words, they are more willing to repay the organization's favorable treatment through continuing participation (Krishnan and Mary., 2012) instead of seeking alternative employment opportunities (Eisenberger et al., 1990). Furthermore, some research has confirmed that high POS can reduce turnover intention. For example, $\mathrm{Ng}$ et al. (2019) reported that high POS would weaken hotel employees' turnover intention by helping them dramatically reduce stress levels in the face of the threat of being replaced by artificial intelligence and robots. And a cross-level study involved 945 Italian nurses showed that POS can prevent nurses' turnover intention by helping members identify with their organization (El Akremi et al., 2014). In addition, meta-analyses have also demonstrated that POS is negatively related to turnover intention (Riggle et al., 2009, Ahmed et al., 2015). Thus, we propose:.

Hypothesis 1: POS is negatively related to turnover intention. 


\subsection{The Mediating Role of Job Crafting}

We argue that POS can affect turnover intention because it can facilitate employees to craft their jobs to achieve a person-job fit, which in turn drives them to decrease turnover intention. Based on the JD-R model (Bakker and Demerouti, 2007), job crafting was defined as the changes employees make in their job demands and job resources with their personal abilities and needs (Tims and Bakker, 2010, Tims et al., 2012). Recently, POS has been regarded as one of the organizational-related factors to predict job-crafting behavior (Cheng and O-Yang, 2018, Kim et al., 2018). Specifically, POS is viewed as the assurance that an organization not only offers employees sufficient resources (Kurtessis et al., 2015, Kim et al., 2019) but also empowers the workforce. Therefore, employees with high POS have access to adequate resources, such as an array of funding, equipment, and other forms of support (Hochwarter et al., 2006). And they also perceive the stability and legitimacy of the power they possess (Loi et al., 2019). Perceiving high levels of organizational support, employees gain a sense of self-efficacy and confidence in optimizing their job (Lazarus, 1991) as well as have the opportunity to wield their power to create autonomy and flexibility for job crafting. Furthermore, according to the conservation of resource theory (Hobfoll, 1989), individuals tend to utilize their existing resources to seek more ones when they have surplus resources. The success of a job crafter may depend largely on resources available to him or her (Berg et al., 2008). Therefore, POS as an additional resource might encourage and assist employees to craft their jobs.

Different from top-down approaches driven by the organization, job crafting initiated by employees is a proactive and bottom-up approach to job redesign (Tims and Bakker, 2010). According to the JD-R model, employees redesign their jobs in terms of their individual abilities and needs rather than reactively perform the jobs that the organization designed. In this way, individuals who establish a person-job fit can fulfill their desire to express personal values and beliefs in their work (Kira and Balkin, 2014). Therefore, employees who customize their jobs to fit their abilities and needs could reduce turnover intention (Kristofbrown et al., 2005, Samad and Saufi, 2017). Furthermore, mounting evidence demonstrates that job crafting can generate beneficial outcomes. For example, Leana et al. (2009) found that childcare teachers become more attached to their jobs and less likely to leave when they experience job crafting. Therefore, we suggest that job crafting serves as a key underlying mechanism by which employees with high POS are less likely to leave the organization. Accordingly, we propose:

Hypothesis 2: Job crafting mediates the relationship between POS and turnover intention.

\subsection{The Mediating Role of Thriving at Work}

We argue that thriving at work mediates the relationship between POS and turnover intention. Spreitzer et al. (2005) defined thriving at work as a positive psychological state characterized by a joint experience of both cognitive (learning) and affective (vitality). Spreitzer et al. (2005) emphasized that individuals are more likely to thrive when they are embedded in unit contexts that advocate a climate of trust and respect and decision-making discretion. Employees with high POS would get a high level of discretion at work that enhances 
motivation to learn new skills and creates a feeling of vitality (Niessen et al., 2017). Furthermore, POS increases the employees' sense of being respected and appreciated (Wiesenfeld et al., 2001) as well as provides a safe haven where employees feel supported and encouraged to "be themselves" (Spreitzer et al., 2012). Consequently, employees with high POS should be more likely to thrive at work.

Turnover intention depends on the individual judgment that can dominate the decision on whether to keep the job or to resign (Hom et al., 2012). When individuals find no opportunity to develop themselves, they want to leave the organization for the other alternatives. Thriving is considered as a subjective experience that conveys a positive sense of progress in one's self-development (Spreitzer et al., 2005) and transforms individual cognition into positive behavioral outcomes (Abid et al., 2019). Furthermore, thriving individuals are more likely to be emotionally attached to their organization (Walumbwa et al., 2018). Meanwhile they would drive themselves to work and keep striving for personal growth and achievement (Jiang, 2017, Spreitzer et al., 2012). Thus, employees who thrive at work would strengthen their willingness to remain (Liu and Bernklug, 2013, Anjum et al., 2016). Based on these inferences, we proposed the following hypothesis:

Hypothesis 3: Thriving at work mediates the relationship between POS and turnover intention.

\subsection{A Serial Mediation Model of POS and Turnover Intention}

The above arguments suggest that both job crafting and thriving at work mediate the relationship between POS and turnover intention, and we further expect that they operate sequentially between the two variables. Employees regard the support from their organization as an incentive (Kurtessis et al., 2015) that can generate their proactive behaviors and psychological states in favor of their self-development, consequently reducing turnover intention. Moreover, as a way for employees to redesign their job, job crafting can help them expand their resources in terms of their needs and preferences whereby the positive and fulfilling psychological states will be generated (Harju et al., 2016). The more resources individuals have at their disposal, the more likely they are to thrive at work (Niessen et al., 2012). Therefore, employees who customize their job demands and job resources via job crafting should thrive at work, which fosters them to be more engaged and effective in their work and subsequently reduces turnover intention. Combining these findings together with our hypotheses above, we suggest a serial mediation model linking POS and turnover intention.

Hypothesis 4: Job crafting and thriving at work sequentially mediate the relationship between POS and turnover intention.

\section{Method}

\subsection{Sample and Procedure}

Data were collected from full-time employees across all different occupations working at several organizations in northern China. Questionnaires were sent through human resource 
departments. We contacted the program managers to explain the purpose of the study and the survey instructions in detail. To encourage respondents' participation, they were informed about confidentiality and anonymity to protect their identity. The data were collected at two different time points. At Time 1, participants answered the survey about demographics, POS and job crafting. After one month, we asked employees involved in the first survey to report the information of thriving at work and turnover intention. Of the 588 questionnaires collected, 47 questionnaires were discarded due to non-completion or missing data. Of the 541 respondents who provided usable surveys, $44 \%$ of them are women. The average age of participants is 32.95 years old $(\mathrm{SD}=8.37$ ), about $62 \%$ of participants are married, and the average tenure with the organization is 5.8 years. Fewer than half of the participants $(24.8 \%$ were first-line managers, $21.8 \%$ were middle-level managers).

\subsection{Measure}

All variables were measured on a five-point Likert scale, ranging from 1 (strongly disagree) to 5 (strongly agree), except control variables in the study. POS was assessed with the 8-item scale developed by Eisenberger et al. (1986). Sample items included "The organization really cares about my well-being" and "I can get immediate assistance if I need it".Turnover intention was evaluated by a scale including four items developed by Mobley et al. (1978). Participants rated their level of approval with statements, such as "I often consider resigning from my current job".Job crafting was measured using the 21-item job crafting scale developed by Tims et al. (2012). Examples are "I decide on my own how I do things" (increasing structural job resources), "I look to my supervisor for inspiration" (Increasing social job resources), "I regularly take on extra tasks even if I didn't get extra salary for them" (Increasing challenging job demands) and "I try to ensure that my work is emotionally less intense" (decreasing hindering job demands). Thriving at work was measured with items from Porath et al. (2012) that are altogether combined into four items to measure vitality (e.g., "I have energy and spirit") and four items to measure learning (e.g., "I continue to learn more as time goes by"). We controlled age, gender, and tenure with organization in all subsequent analyses because those variables have been found to affect turnover intention (Bal et al., 2013, Mynatt et al., 1997).

\section{Data Analysis and Results}

\subsection{Tests of Reliability, Validity, and Common Method Variance}

The means, standard deviations (SD), correlations, Cronbach's alphas and composite reliabilities (CR) of the variables are presented in Table 1. We first implemented Confirmatory factor analysis (CFA) to assess the convergent and discriminant validity using Mplus 7.4. The composite reliabilities ranged from 0.90 to 0.93 , which confirmed the convergent validity of the research measures. Based on the procedure proposed by Fornell and Larcker (1981). We further assessed the discriminant validity between study variables. Table 1 also showed that all average variance extracted was higher than the squared correlation between the target construct and any of the others. Overall, our constructs showed sound measurement properties. 
Table 1. Means, standard deviation, and correlations

\begin{tabular}{lcccccccc}
\hline & 1 & 2 & 3 & 4 & 5 & 6 & 7 & 8 \\
\hline 1.Gender & - & & & & & & & \\
2.Age & 0.01 & - & & & & & & \\
3.tenure & 0.07 & $0.74^{* *}$ & - & & & & & \\
4.position & $0.23^{* *}$ & $0.15^{* *}$ & $0.24^{* *}$ & - & & & & \\
5.POS & -0.02 & 0.08 & -0.01 & -0.08 & 0.77 & & & \\
6.job crafting & -0.04 & 0.04 & -0.08 & $-0.12^{* *}$ & $0.43^{* *}$ & 0.72 & & \\
7.thriving at work & -0.02 & 0.01 & -0.05 & $-0.13^{* *}$ & $0.41^{* *}$ & $0.66^{* *}$ & 0.75 & \\
8.turnover intention & 0.07 & -0.08 & 0.00 & 0.08 & $-0.08^{*}$ & $-0.16^{* *}$ & $-0.23^{* *}$ & 0.80 \\
$\quad$ Mean & 0.44 & 31.95 & 5.88 & 1.68 & 3.31 & 3.85 & 3.86 & 2.94 \\
$\quad$ SD & 0.49 & 8.37 & 5.63 & 0.81 & 0.63 & 0.51 & 0.62 & 0.88 \\
Cronbach's $\alpha$ & & & & & 0.89 & 0.84 & 0.87 & 0.86 \\
CR & & & & & 0.91 & 0.93 & 0.91 & 0.91 \\
\hline
\end{tabular}

Notes: $N=541 ;{ }^{*} P<0.05 ;{ }^{* *} P<0.01 . S D=$ standard deviation, $C R=$ composite reliability. The numbers in the diagonal are the average variance extracted (AVE).

CFA was also conducted to test the construct validity of the scale variables of POS, job crafting, thriving at work and turnover intention. The four-factor measurement model showed an adequate fit to the data: $\chi 2 / \mathrm{df}=3.07, \mathrm{TLI}=0.94, \mathrm{CFI}=0.95, \mathrm{RMSEA}=0.05, \mathrm{SRMR}=$ 0.07. The model fit was superior to other alternatives, indicating that participants could distinguish between POS, turnover intention, job crafting and thriving at work.

\subsection{Hypothesis Testing}

To test the hypothesized model (Figure 1), we conducted a hierarchical linear regression analysis with the PROCESS plug-in for SPSS to determine the significance of mediators. The results of the hypotheses tests are shown in Figure1. The total effect of POS on turnover intention was negative and significant $(\beta=-0.102, \mathrm{P}<0.001)$, thereby supporting $\mathrm{H} 1$. However, when mediators (job crafting and thriving at work) were added, the direct effect of POS on turnover intention ( $\beta=0.023$, ns) was dramatically decreased and nullified. Thus, this total effect is not direct, but basically indirect. The effect of POS on turnover intention was determined via the two mediators. 

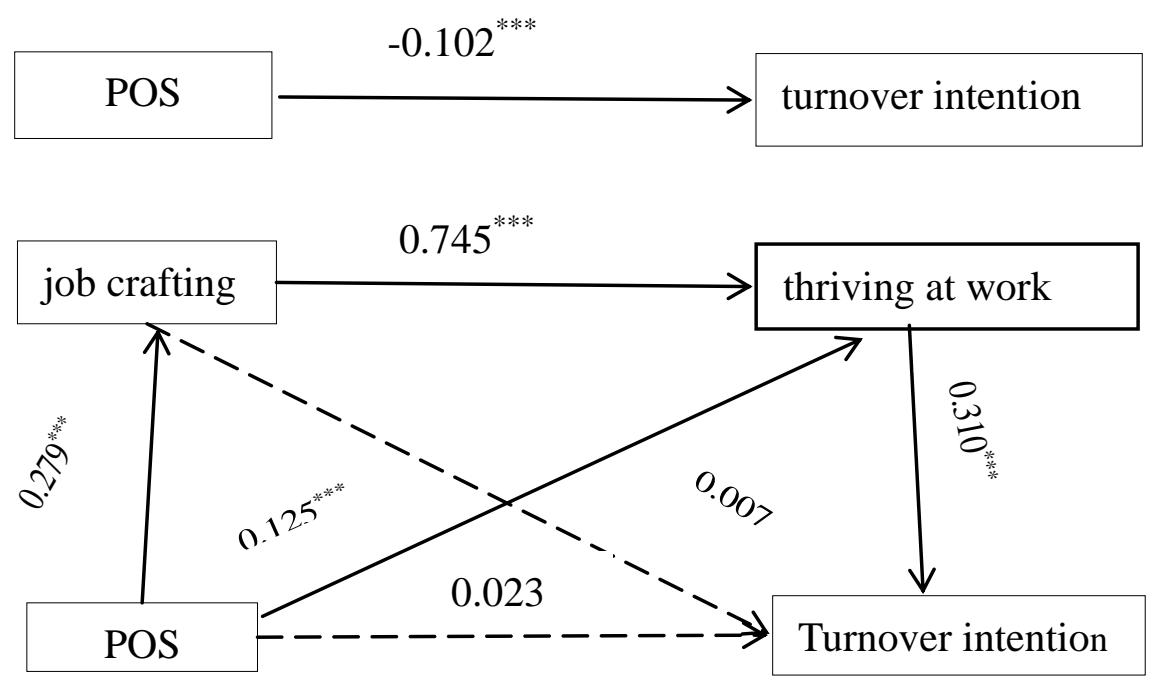

Figure 1. Three-path mediation model

Notes: $N=541 ;{ }^{* * *} p<0.001$

Regarding the test of the study's mediation model, $H 2, H 3$, and $H 4$ were tested. As shown in Figure1, Table 2 and Table 3, there is a positive relationship between POS and job crafting ( $\beta$ $=0.279, P<0.001)$. However, job crafting was not significantly related to turnover intention $(\beta=0.007, \mathrm{~ns})$, and the bootstrapped estimate of the indirect effect $(\beta=0.002, \mathrm{~ns} ; 95 \% \mathrm{CI}=$ $[-0.057,0.068])$ indicated a non-significant effect. Thus $H 2$ was rejected. For $H 3$, the result revealed that POS predicted thriving at work $(\beta=0.125, P<0.001)$ and that thriving at work predicted turnover intention $(\beta=-0.310, P<0.001)$, as confirmed by the bias-corrected bootstraps at a 95-percent confidence interval $(\beta=-0.065, P<0.001 ; 95 \% \mathrm{CI}=[-0.106$, -0.028]), thus $H 3$ was supported. Finally, to test $H 4$, we estimated sequential multiple mediations by adding mediators (job crafting and thriving at work). As predicted, the indirect effect of POS on turnover intention through job crafting and thriving at work was statistically significant $(\beta=-0.039, P<0.001 ; 95 \% \mathrm{CI}=[-0.086,-0.012])$, thus giving support to $H 4$. In sum, these findings indicated that the negative relationship between POS and turnover intention was fully and sequentially mediated by job crafting and thriving at work.

Table 2. Regression coefficient, standard errors and model summary

\begin{tabular}{|c|c|c|c|c|c|c|c|c|c|}
\hline \multirow{2}{*}{ Variables } & \multicolumn{3}{|c|}{ job crafting } & \multicolumn{3}{|c|}{ thriving at work } & \multicolumn{3}{|c|}{ turnover intention } \\
\hline & Coeff. & $S E$ & $P$ & Coeff. & $S E$ & $P$ & Coeff. & $S E$ & $P$ \\
\hline POS & 0.279 & 0.026 & $\begin{array}{c}< \\
0.001\end{array}$ & 0.125 & 0.030 & $<0.001$ & 0.023 & 0.056 & ns \\
\hline job crafting & - & - & - & 0.745 & 0.045 & $<0.001$ & 0.007 & 0.102 & $\mathrm{~ns}$ \\
\hline thriving at work & - & - & - & - & - & - & -0.310 & 0.080 & $\begin{array}{c}< \\
0.001\end{array}$ \\
\hline constant & 2.765 & 0.129 & $\begin{array}{c}< \\
0.001\end{array}$ & 0.743 & 0.184 & $<0.001$ & 4.351 & 0.343 & $\begin{array}{c}< \\
0.001\end{array}$ \\
\hline age & 0.008 & 0.003 & 0.019 & -0.005 & 0.004 & $\mathrm{~ns}$ & -0.160 & 0.007 & 0.017 \\
\hline
\end{tabular}




\section{MlMacrothink}

International Journal of Human Resource Studies

ISSN 2162-3058

2021, Vol. 11, No. 1

$\begin{array}{lccccccccc}\text { gender } & -0.001 & 0.039 & \mathrm{~ns} & 0.028 & 0.042 & \mathrm{~ns} & 0.836 & 0.078 & \mathrm{~ns} \\ \text { tenure } & -0.014 & 0.005 & 0.006 & 0.006 & 0.005 & \mathrm{~ns} & 0.013 & 0.010 & \mathrm{~ns} \\ \text { position } & -0.045 & 0.025 & \mathrm{~ns} & -0.043 & 0.026 & \mathrm{~ns} & 0.049 & 0.048 & \mathrm{~ns}\end{array}$
$R^{2}$
$R^{2}=0.208$
$R^{2}=0.454$
$R^{2}=0.656$

$F$-value

$$
F(5,535)=28.041, P<0.001 F(6,534)=74.017, P<0.001 F(7,533)=145.203, P<0.001
$$

Notes: $N=541 ; n s=$ not significant .

Table 3. The total, direct and indirect effects

\begin{tabular}{lcc}
\hline \multicolumn{1}{c}{ Model } & Coeff. & \multicolumn{2}{c}{ Bootstrapping 95\%CI } \\
\cline { 3 - 3 } The total effect of POS on turnover & -0.102 & Lower \\
Direct effect of POS on turnover & 0.023
\end{tabular}

Indirect effects of POS on turnover

$\mathrm{H} 2$ : POS - job crafting - turnover intention

$0.002 \quad-0.057 \quad 0.068$

H3: POS - thriving at work- turnover intention

$-0.065 \quad-0.106 \quad-0.028$

H4: POS - job crafting - thriving at work - turnover intention

$\begin{array}{lll}-0.039 & -0.086 & -0.012\end{array}$

Total indirect effect

$-0.102-0.173$

$-0.036$

Notes: $N=541$.

\section{Discussion}

In this study, findings supported that POS was indirectly related to turnover intention and revealed two favorable pathways according to which employees inclined to remain. First, the detected mediating role of thriving at work revealed a mechanism by which POS could reduce turnover intention. Employees with high POS tend to devote their time and effort into requiring knowledge and skills. The more time and effort people invest, the more embedded they would become in the organization. Second, we further found from the serial mediation test that POS affected less turnover intention via job crafting and thriving at work. We proposed that POS is an important organizational factor that facilitates employees to customize their job. If job demands and job resources are in balance, individuals might have a healthy psychological state which lessens the turnover intention.

However, we found that though POS created the condition that facilitated job crafting, this behavior didn't significantly affect turnover intention. There are three explanations for this result. First, job crafting measured here is originally derived from the JD-R theory with the intention of aligning employees' jobs with their needs and preferences. Accordingly, job crafting may not be consistent with the goals of the organization. The person-organization fit wouldn't be improved because of different goals and values, even if employees achieve the 
person-job fit through job carting. Then the intention to leave couldn't decrease. Second, a meta-synthesis of qualitative job crafting research found that when employees fail to meet expected goals during the job crafting attempt because of some constrained factors such as interference by other people and overestimation of their abilities, they would be exposed to negative experiences (Lazazzara et al., 2019). Finally, there may be an offsetting effect between decreasing hindering job demands and other dimensions. We expect that increasing resources and challenge job demands would reduce turnover intention. However, it is plausible that decreasing hindering job demands may increase turnover intention and serve to offset the positive influence (Bruning and Campion, 2018).

\subsection{Theoretical Implications}

Our study contributes to several streams of research by examining the relationships among POS, turnover intention, job crafting and thriving at work. First, the most important theoretical contribution of this study is that it extends the prior studies on the POS-turnover intention relationship by introducing the mediating roles of job crating and thriving at work. Meanwhile we respond to the call by Maertz et al. (2007) who suggested that more studies need to focus on other mechanisms beyond organizational attitudes. We find that proactive behaviors and positive psychological states might be another mechanism that transforms organizational support to less turnover intention. Second, our results enrich and expand the socially embedded model of thriving at work. We find that POS generates thriving at work because of enhancing decision-making discretion and climate of trust and respect. This finding works in concert with other research that underlines the importance of a supportive work environment for thriving (Abid et al., 2016). In fact, Abid et al. (2015) first proposed the thriving at work as a mediating role liking POS and turnover intention but their results didn't support this hypothesis. Then they called for more research to explore this mediating role. The present study responds to this call and confirms this hypothesis by showing the empirical evidence that POS minimizes the turnover intention through thriving at work. In addition, a small number of studies started to investigate the impact of active work behaviors on thriving at work. For example, Kira and Balkin (2014) first considered job crafting as one of antecedents of thriving but they did not prove it. To address this gap, this study empirically supports the viewpoint that thriving at work can be enhanced by job crafting. Lastly, this study adds to the existing body of job crafting literature. Few studies have examined employees' perceptions of situational factors (e.g., POS) as a predictor of job crafting (Kim et al., 2018). Consistent with previous studies, this study provides new insight and empirical evidence to confirm that POS tends to trigger employees' job crafting. Moreover, although we fail to verify job crafting as a mediating role linking POS with turnover intention, this study also advances the research on the effect of job crafting on turnover intention. In fact, there is a distinction between the results of research on this effect. Rudolph et al. (2017) reported that job crafting as a set did not significantly affect turnover intention. However, another study (Dominguez et al., 2018) suggested that only two of the four job crafting skills (increase structural resources and reducing hindering demands) were related to the intention to leave but in a contrary direction. In line with Rudolph et al. (2017), this study confirms that there is a non-significant relationship between overall job crafting and turnover intention, 
which indicates there may be an offset effect on the relationship between the four job crafting dimensions and turnover intention.

\subsection{Practical Implications}

The findings of this study have some practical implications for managers to redesign human resource management strategies to minimize employees' turnover intention. First, we suggest that a supportive work environment that inspires employees to redesign their job and thrive at work plays an important role in helping retain staff. Thus, we recommend managers to take measures to enhance employees' perceptions of organizational support through coaching, active listening skills, creating a sharing climate and providing organizational incentives to establish a better relationship between employees and organizations. In addition, we consider that both job crating and thriving at work are part of the self-development process coping with organization environment. This self-development process could be a useful strategy to maintain positive work experience and make employees more satisfied with their work.

\subsection{Limitations and Suggestions for Future Research}

This study also has some limitations. First, our results may be affected by CMV because of single-source data. Although this study has a one-month interval of measurement, the design of this study is not strictly longitudinal, which makes it difficult to establish a causal relationship between study variables. Therefore, in future research, it is necessary to test the causal relationship of this paper through multi-source data and more rigorous research designs. Second, we examined job crafting as a set and failed to figure out the specific relationship between the four dimensions of job crafting and turnover intention. As mentioned above, we suggest that not all job crafting behavior necessarily decreases turnover intention. Therefore, future research can focus on the relationship between specific forms of job crafting and turnover intention.

\section{Conclusion}

This study advances the growing body of research on POS-turnover intention relationships by building and testing a serial mediation model. Using a Chinese sample, the results indicated that job crafting and thriving at work can transform POS into less turnover intention. Our study highlights that it might be better understood the POS-turnover intention relationships by focusing on the employees' self-development process. We urge that future research will pay attention to employees' proactivity at work to explain job-related outcomes.

\section{Acknowledgments}

This study was supported by National Natural Science Foundation of China (Grant number 72071124) and Education of Humanities and Social Sciences Research on Planning Foundation of China (Grant number 18YJA630145).

\section{References}

Abid, G., Contreras, F., Ahmed, S., \& Qazi, T. (2019). Contextual Factors and Organizational Commitment: Examining the Mediating Role of Thriving at Work. Sustainability, 11(17), 
https://doi.org/10.3390/su11174686

Abid, G., Zahra, I., \& Ahmed, A. (2015). Mediated mechanism of thriving at work between perceived organization support, innovative work behavior and turnover intention. Pakistan Journal of Commerce and Social Sciences, 9(3), 982-998.

Abid, G., Zahra, I., \& Ahmed, A. (2016). Promoting thriving at work and waning turnover intention: A relational perspective. Future Business Journal, 2(2), 127-137. https://doi.org/10.1016/j.fbj.2016.08.001

Afsar, B., \& Badir, Y. F. (2016). Person-organization fit, perceived organizational support, and organizational citizenship behavior: The role of job embeddedness. Journal of Human $\begin{array}{llll}\text { Resources in Hospitality \& } \quad \text { Tourism, } & 15(3), & 252-278 .\end{array}$ https://doi.org/10.1080/15332845.2016.1147936

Ahmed, I., Nawaz, M. M., Ali, G., \& Islam, T. (2015). Perceived organizational support and its outcomes. Management Research Review, 38(6), 627-639. https://doi.org/10.1108/MRR-09-2013-0220

Allen, D. G., Shore, L. M., \& Griffeth, R. W. (2003). The Role of Perceived Organizational Support and Supportive Human Resource Practices in the Turnover Process. Journal of Management, 29(1), 99-118. https://doi.org/10.1016/S0149-2063(02)00222-2

Anjum, M. A., Marr, S., \& Khan, H. (2016). Thriving at work: Evidences from Telecom companies in Balochistan. Gomal University Journal of Research, 32(2), 36-46.

Antonacopoulou, E. P. (2000). Employee development through self-development in three retail banks. Personnel Review, 29(4), 491-508. https://doi.org/10.1108/00483480010296294

Arshadi, N. (2011). The relationships of perceived organizational support (POS) with organizational commitment, in-role performance, and turnover intention: Mediating role of felt obligation. Procedia-Social and Behavioral Sciences, 30, 1103-1108. https://doi.org/10.1016/j.sbspro.2011.10.215

Bakker, A. B., \& Demerouti, E. (2007). The Job Demands-Resources model: state of the art. $\begin{array}{llll}\text { Journal of } \quad \text { Managerial } & \text { Psychology, } 22(3),\end{array}$ https://doi.org/10.1108/02683940710733115

Bal, P. M., De Cooman, R., \& Mol, S. T. (2013). Dynamics of psychological contracts with work engagement and turnover intention: The influence of organizational tenure. European Journal of Work and Organizational Psychology, 22(1), 107-122. https://doi.org/10.1080/1359432X.2011.626198

Baranik, L., Roling, E. A., \& Eby, L. T. (2010). Why Does Mentoring Work? The Role of Perceived Organizational Support. Journal of Vocational Behavior, 76(3), 366-373. https://doi.org/10.1016/j.jvb.2009.07.004

Berg, j. M., Dutton, J. E., \& Wrzesniewski, A. (2008). What is Job Crafting and Why Does It Matter. $\quad$ Retrieved January 2008 from 
https://www.unglobalcompact.org/take-action/action/womens-principles

Bogler, R., \& Nir, A. E. (2012). The Importance of Teachers' Perceived Organizational Support to Job Satisfaction: What's Empowerment Got to Do with It? Journal of Educational Administration, 50(3), 287-306. https://doi.org/10.1108/09578231211223310

Bruning, P. F., \& Campion, M. A. (2018). A role-resource approach-avoidance model of job crafting: A multimethod integration and extension of job crafting theory. Academy of Management Journal, 61(2), 499-522. https://doi.org/10.5465/amj.2015.0604

Celep, C., \& Yilmazturk, O. E. (2012). The Relationship among Organizational Trust, Multidimensional Organizational Commitment and Perceived Organizational Support in Educational Organizations. Procedia-Social and Behavioral Sciences, 46, 5763-5776. https://doi.org/10.5539/ies.v8n11p219

Cheng, J.-C., \& O-Yang, Y. (2018). Hotel employee job crafting, burnout, and satisfaction: The moderating role of perceived organizational support. International Journal of Hospitality Management, 72, 78-85. https://doi.org/10.1016/j.ijhm.2018.01.005

Chiang, C., \& Hsieh, T. (2012). The impacts of perceived organizational support and psychological empowerment on job performance: the mediating effects of organizational citizenship behavior. International Journal of Hospitality Management, 31(1), 180-190. https://doi.org/10.1016/j.ijhm.2011.04.011

Dawley, D., Houghton, J. D., \& Bucklew, N. S. (2010). Perceived organizational support and turnover intention: the mediating effects of personal sacrifice and job fit. The Journal of Social Psychology, 150(3), 238-257. https://doi.org/10.1080/00224540903365463

DeConinck, J. B., \& Johnson, J. T. (2009). The effects of perceived supervisor support, perceived organizational support, and organizational justice on turnover among salespeople. Journal of Personal Selling \& Sales Management, 29(4), 333-350. https://doi.org/10.2753/PSS0885-3134290403

Dominguez, L. C., Stassen, L., de Grave, W., Sanabria, A., Alfonso, E., \& Dolmans, D. (2018). Taking control: Is job crafting related to the intention to leave surgical training? PLoS One, 13(6), e0197276. https://doi.org/10.1371/journal.pone.0197276

Eisenberger, R., Armeli, S., Rexwinkel, B., Lynch, P., \& Rhoades, L. (2001). Reciprocation of perceived organizational support. Journal of Applied psychology, 86(1), 42-51. https://doi.org/10.1037/0021-9010.86.1.42

Eisenberger, R., Fasolo, P. M., \& Davislamastro, V. (1990). Perceived Organizational Support and Employee Diligence, Commitment, and Innovation. Journal of Applied psychology, 75(1), 51-59. https://doi.org/10.1037/0021-9010.75.1.51

Eisenberger, R., Huntington, R., Hutchison, S., \& Sowa, D. (1986). Perceived organizational $\begin{array}{lllll}\text { support. Journal of } & \text { Applied }\end{array}$ https://doi.org/10.1037/0021-9010.71.3.500 
Eisenberger, R., \& Stinglhamber, F. (2011). Perceived organizational support: Fostering enthusiastic and productive employees. Washington, DC, US: American Psychological Association. https://doi.org/10.1037/12318-000

El Akremi, A., Colaianni, G., Portoghese, I., Galletta, M., \& Battistelli, A. (2014). How organizational support impacts affective commitment and turnover among Italian nurses: A multilevel mediation model. The International Journal of Human Resource Management, 25(9), 1185-1207. doi:10.1080/09585192.2013.826713 https://doi.org/10.1080/09585192.2013.826713

Fornell, C., \& Larcker, D. F. (1981). Evaluating structural equation models with unobservable variables and measurement error. Journal of marketing research, 18(1), 39-50. https://doi.org/10.2307/3151312

Griffeth, R. W., Hom, P. W., \& Gaertner, S. (2000). A meta-analysis of antecedents and correlates of employee turnover: Update, moderator tests, and research implications for the next millennium. Journal of Management, 26(3), 463-488. https://doi.org/10.1177/014920630002600305

Harju, L. K., Hakanen, J. J., \& Schaufeli, W. B. (2016). Can job crafting reduce job boredom and increase work engagement? A three-year cross-lagged panel study. Journal of Vocational Behavior, 95-96, 11-20. https://doi.org/10.1016/j.jvb.2016.07.001

He, H., Pham, H. Q., Baruch, Y., \& Zhu, W. (2014). Perceived organizational support and organizational identification: joint moderating effects of employee exchange ideology and employee investment. The International Journal of Human Resource Management, 25(20), 2772-2795. https://doi.org/10.1080/09585192.2014.908315

Hobfoll, S. E. (1989). Conservation of resources: A new attempt at conceptualizing stress. American Psychologist, 44(3), 513-524. https://doi.org/10.1037/0003-066X.44.3.513

Hochwarter, W. A., Witt, L. A., Treadway, D. C., \& Ferris, G. R. (2006). The interaction of social skill and organizational support on job performance. Journal of Applied psychology, 91(2), 482-489. https://doi.org/10.1037/0021-9010.91.2.482

Holtom, B. C., Mitchell, T. R., Lee, T. W., \& Eberly, M. B. (2008). Turnover and Retention Research: A Glance at the Past, a Closer Review of the Present, and a Venture into the Future. The Academy of Management Annals, 2(1), 231-274. https://doi.org/10.1080/19416520802211552

Hom, P. W., Mitchell, T. R., Lee, T. W., \& Griffeth, R. W. (2012). Reviewing employee turnover: focusing on proximal withdrawal states and an expanded criterion. Psychological Bulletin, 138(5), 831. https://doi.org/10.1037/a0027983

Hur, W.-M., Moon, T.-W., \& Choi, W.-H. (2019). The Role of Job Crafting and Perceived Organizational Support in the Link between Employees' CSR Perceptions and Job Performance: A Moderated Mediation Model. Current Psychology. https://doi.org/10.1007/s12144-019-00242-9 
Jiang, Z. (2017). Proactive personality and career adaptability: The role of thriving at work. Journal of Vocational Behavior, 98, 85-97. https://doi.org/10.1016/j.jvb.2016.10.003

Kim, C. Y., Lee, J. H., \& Shin, S. Y. (2019). Why Are Your Employees Leaving the Organization? The Interaction Effect of Role Overload, Perceived Organizational Support, and Equity Sensitivity. Sustainability, 11(3). https://doi.org/10.3390/su11030657

Kim, H., Im, J., \& Qu, H. (2018). Exploring antecedents and consequences of job crafting. International Journal of Hospitality Management, $\quad 75, \quad$ 18-26. https://doi.org/10.1016/j.ijhm.2018.02.014

Kira, M., \& Balkin, D. B. (2014). Interactions between work and identities: Thriving, withering, or redefining the self? Human Resource Management Review, 24(2), 131-143. https://doi.org/10.1016/j.hrmr.2013.10.001

Krishnan, J., \& Mary., V. S. (2012). Perceived organisational support-an overview on its antecedents and consequences. International Journal of Multidisciplinary Research, 2(4), 1-13. https://doi.org/10.3390/su11030657

Kristofbrown, A. L., Zimmerman, R. D., \& Johnson, E. C. (2005). Consequences of Individuals' Fit at Work : A Meta-analysis of Person-job, Person-organization Person-group, And Person-supervisor Fit . Personnel Psychology, 58(2), 281-342. https://doi.org/10.1111/j.1744-6570.2005.00672.x

Kurtessis, J. N., Eisenberger, R., Ford, M. T., Buffardi, L. C., Stewart, K. A., \& Adis, C. S. (2015). Perceived Organizational Support: A Meta-Analytic Evaluation of Organizational Support Theory. Journal of Management, 43(6), 1854-1884. https://doi.org/10.1177/0149206315575554

Lazarus, R. S. (1991). Progress on a cognitive-motivational-relational theory of emotion. American Psychologist, 46(8), 819-834. https://doi.org/10.1037/0003-066X.46.8.819

Lazazzara, A., Tims, M., \& De Gennaro, D. (2019). The process of reinventing a job: A meta-synthesis of qualitative job crafting research. Journal of Vocational Behavior, 116, https://doi.org/10.1016/j.jvb.2019.01.001

Leana, C. R., Appelbaum, E., \& Shevchuk, I. (2009). Work Process and Quality of Care in Early Childhood Education: The Role of Job Crafting. Academy of Management Journal, 52(6), 1169-1192. https://doi.org/10.5465/amj.2009.47084651

Liu, J., \& Bernklug, M. (2013). Nursing home social services directors who report thriving at work. Journal of Gerontological Social Work, 56(2), 127-145. https://doi.org/10.1080/01634372.2012.750255

Loi, R., Lin, X., \& Tan, A. J. M. (2019). Powered to craft? The roles of flexibility and perceived organizational support. Journal of Business Research, 104, 61-68. https://doi.org/10.1016/j.jbusres.2019.07.002

Maertz, C. P., Griffeth, R. W., Campbell, N. S., \& Allen, D. G. (2007). The effects of 
perceived organizational support and perceived supervisor support on employee turnover. Journal of Organizational Behavior, 28(8), 1059-1075. https://doi.org/10.1002/job.472

Meijerink, J., Bos-Nehles, A., \& de Leede, J. (2018). How employees' pro-activity translates high-commitment HRM systems into work engagement: the mediating role of job crafting. The International Journal of Human Resource Management, 1-26. https://doi.org/10.1080/09585192.2018.1475402

Mobley, W. H., Horner, S. O., \& Hollingsworth, A. T. (1978). An evaluation of precursors of hospital employee turnover. Journal of Applied psychology, 63(4), 408. https://doi.org/10.1037/0021-9010.63.4.408

Mynatt, P. G., Omundson, J. S., Schroeder, R. G., \& Stevens, M. B. (1997). The impact of Anglo and Hispanic ethnicity, gender, position, personality and job satisfaction on turnover intentions: a path analytic investigation. Critical perspectives on accounting, 8(6), 657-683. https://doi.org/10.1006/cpac.1997.0161

Ng, K.-Y., Van Dyne, L., \& Ang, S. (2019). Speaking out and speaking up in multicultural settings: A two-study examination of cultural intelligence and voice behavior. Organizational Behavior and Human Decision Processes, 151, 150-159. https://doi.org/10.1016/j.obhdp.2018.10.005

Ngo, H., Loi, R., Foley, S., Zheng, X., \& Zhang, L. (2013). Perceptions of organizational context and job attitudes: The mediating effect of organizational identification. Asia Pacific Journal of Management, 30(1), 149-168. https://doi.org/10.1007/s10490-012-9289-5

Nielsen K., Stage M., Abildgaard J.S., Brauer C.V. (2013) Participatory Intervention from an Organizational Perspective: Employees as Active Agents in Creating a Healthy Work Environment. In: Bauer G., Jenny G. (eds) Salutogenic organizations and change (pp.327-350). Springer, Dordrecht. https://doi.org/10.1007/978-94-007-6470-5_18

Niessen, C., Mäder, I., Stride, C., \& Jimmieson, N. L. (2017). Thriving when exhausted: The role of perceived transformational leadership. Journal of Vocational Behavior, 103, 41-51. https://doi.org/10.1016/j.jvb.2017.07.012

Niessen, C., Sonnentag, S., \& Sach, F. (2012). Thriving at work-A diary study. Journal of Organizational Behavior, 33(4), 468-487. https://doi.org/10.1002/job.763

Paillé, P. (2015). Perceived organizational support and work outcomes. International Journal of Organizational Analysis, 23(2), 191-212. https://doi.org/10.1108/IJOA-11-2012-0627

Panaccio, A., \& Vandenberghe, C. (2009). Perceived organizational support, organizational commitment and psychological well-being: A longitudinal study. Journal of Vocational Behavior, 75(2), 224-236. https://doi.org/10.1016/j.jvb.2009.06.002

Park, J. H., Newman, A., Zhang, L., Wu, C., \& Hooke, A. (2015). Mentoring functions and turnover intention: the mediating role of perceived organizational support. The International Journal of Human Resource Management, 27(11), 1173-1191. https://doi.org/10.1080/09585192.2015.1062038 
Pfeffer, J. (2005). Producing sustainable competitive advantage through the effective management of people. Academy of Management Perspectives, 19(4), 95-106. https://doi.org/10.5465/ame.1995.9503133495

Porath, C., Spreitzer, G., Gibson, C., \& Garnett, F. G. (2012). Thriving at work: Toward its measurement, construct validation, and theoretical refinement. Journal of Organizational Behavior, 33(2), 250-275. https://doi.org/10.1002/job.756

Rhoades, L., \& Eisenberger, R. (2002). Perceived organizational support: A review of the $\begin{array}{llll}\text { literature. Journal of Applied } & \text { psychology, } & \text { 87(4), }\end{array}$ https://doi.org/10.1037/0021-9010.87.4.698

Riggle, R. J., Edmondson, D. R., \& Hansen, J. D. (2009). A meta-analysis of the relationship between perceived organizational support and job outcomes: 20 years of research. Journal of Business Research, 62(10), 1027-1030. https://doi.org/10.1016/j.jbusres.2008.05.003

Rudolph, C. W., Katz, I. M., Lavigne, K. N., \& Zacher, H. (2017). Job crafting: A meta-analysis of relationships with individual differences, job characteristics, and work outcomes. Journal of Vocational Behavior, 102, 112-138. https://doi.org/10.1016/j.jvb.2017.05.008

Samad, A., \& Saufi, R. A. (2017). A Comparative Review of Turnover Models and Recent Trends in Turnover Literature. Journal of Management and Marketing Review, 2(4), 27-35.

Spreitzer, G., Porath, C. L., \& Gibson, C. B. (2012). Toward human sustainability. Organizational Dynamics, 41(2), 155-162. https://doi.org/10.1016/j.orgdyn.2012.01.009

Spreitzer, G. M., Sutcliffe, K. M., Dutton, J. E., Sonenshein, S., \& Grant, A. M. (2005). A Socially Embedded Model of Thriving at Work. Organization Science, 16(5), 537-549. https://doi.org/10.1287/orsc.1050.0153

Steel, R. P., \& Lounsbury, J. W. (2009). Turnover process models: Review and synthesis of a conceptual literature. Human Resource Management Review, 19(4), 271-282. https://doi.org/10.1016/j.hrmr.2009.04.002

Tims, M., \& Bakker, A. B. (2010). Job crafting_ Towards a new model of individual job redesign. SA Journal of Industrial Psychology. $36(2), \quad 1-9$. https://doi.org/10.1016/j.jvb.2011.05.009

Tims, M., Bakker, A. B., \& Derks, D. (2012). Development and validation of the job crafting scale. Journal of Vocational Behavior, 80(1), 173-186. https://doi.org/10.1016/j.jvb.2011.05.009

Walumbwa, F. O., Muchiri, M. K., Misati, E., Wu, C., \& Meiliani, M. (2018). Inspired to perform: A multilevel investigation of antecedents and consequences of thriving at work. Journal of Organizational Behavior, 39(3), 249-261. https://doi.org/10.1002/job.2216

Wiesenfeld, B. M., Raghuram, S., \& Garud, R. (2001). Organizational identification among virtual workers: The role of need for affiliation and perceived work-based social support. 


\section{Macrothink}

International Journal of Human Resource Studies

ISSN 2162-3058 2021, Vol. 11, No. 1

Journal of Management, 27(2), 213-229. https://doi.org/10.1016/S0149-2063(00)00096-9

Zopiatis, A., Constanti, P., \& Theocharous, A. L. (2014). Job involvement, commitment, satisfaction and turnover: Evidence from hotel employees in Cyprus. Tourism Management, 41, 129-140. https://doi.org/10.1016/j.tourman.2013.09.013

\section{Copyright Disclaimer}

Copyright for this article is retained by the author(s), with first publication rights granted to the journal.

This is an open-access article distributed under the terms and conditions of the Creative Commons Attribution license (http://creativecommons.org/licenses/by/4.0/). 